\title{
Piękny Jubileusz 90. urodziny Doktor Cecylii Iwaniszewskiej
}

Od 53 lat jest z nami w Towarzystwie Miłośników Torunia, od 51 lat jest członkinią Zarządu, przez wiele lat pełniła w nim funkcję sekretarza. W 2001 r. otrzymała Złote Astrolabium, nasze najwyższe odznaczenie. Od 1996 r., z ramienia ToMiTo, współpracuje nieprzerwanie z Radą Miasta Torunia w zakresie nazewnictwa ulic. Jest laureatką wielu nagród, m.in. „Za zasługi dla Miasta Torunia” na wstędze (2013). Jest również aktywną uczestniczką corocznej kwesty na cmentarzu św. Jerzego w Toruniu... wyliczać można długo. To nieprzeciętna kobieta, naukowiec, społecznik, wspaniały człowiek.

Prace naszej Cecylii na rzecz miasta i regionu docenili w roku jej 90. urodzin zarówno prezydent Torunia Michał Zaleski, który uhonorował ją Medalem Thorunium 21 listopada 2018 r. (w trakcie uroczystości jubileuszowej w Klubie Inteligencji Katolickiej w Toruniu), jak i Piotr Całbecki, który wręczył Jej Medal Marszałka Województwa KujawskoPomorskiego z okazji 100 lat Niepodległości.

Ta ostatnia uroczystość miała szczególny charakter, odbyła się 29 listopada tego roku w Książnicy Kopernikańskiej w Toruniu. Przybyli na nią przyjaciele z ToMiTo, Stowarzyszenia Absolwentów UMK, Książnicy Kopernikańskiej, mieszkańcy miasta, i nie tylko. Piękne i mądre słowa skierował do Jubilatki Piotr Całbecki, marszałek województwa kujawsko-pomorskiego. Została także obdarowana szczególnym prezentem, albumem wydrukowanym tylko dla Niej, i tylko w jednym egzemplarzu (Kobieta Niezwykła Cecylia Maria z Eubieńskich Iwaniszewska, 


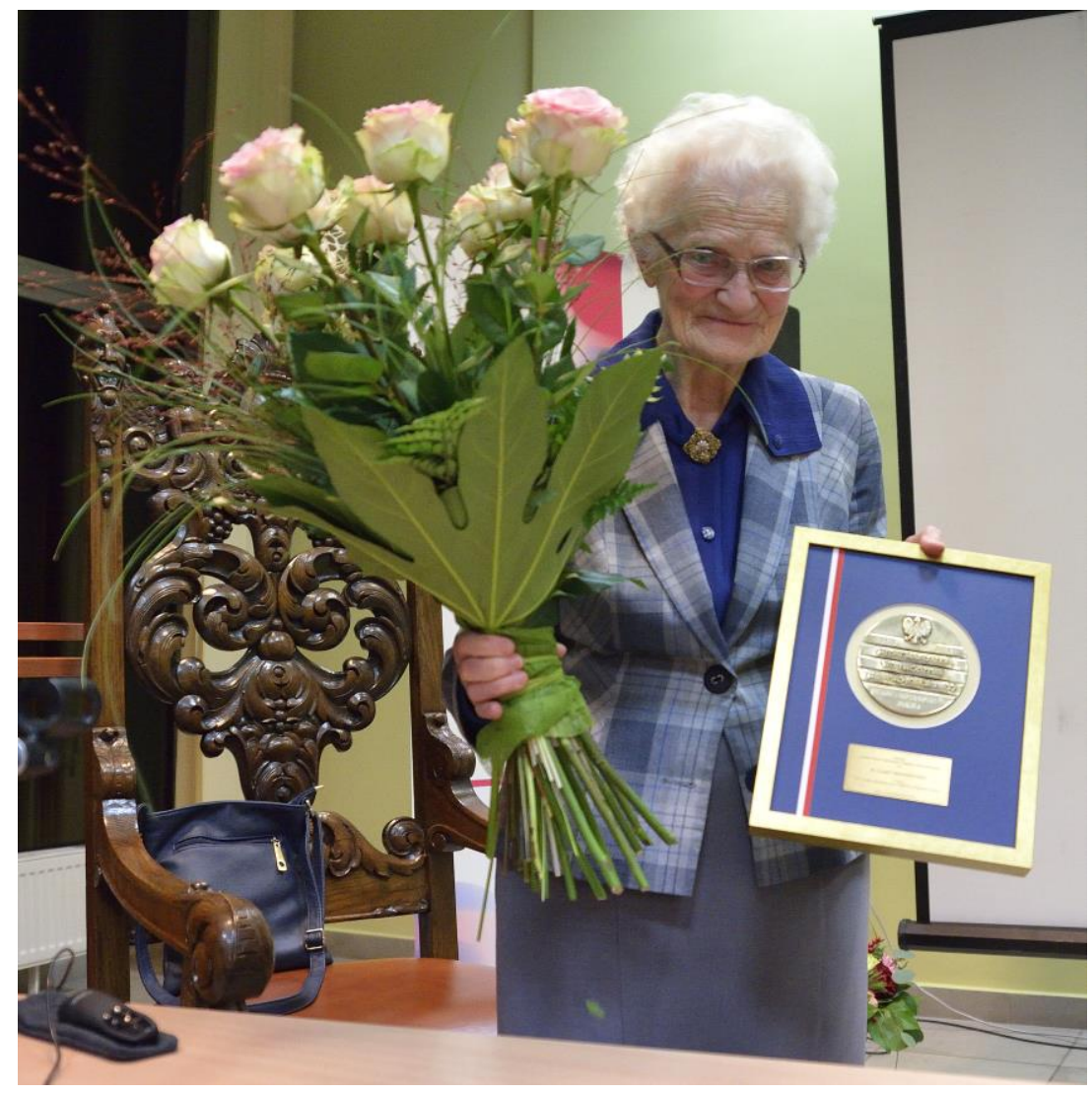

Cecylia z Łubieńskich Iwaniszewska, fot. T. Dorawa

pod red. Aliny Daukszy-Wiśniewskiej i Katarzyny Tomkowiak, Toruń 2018). Niespodziankę przygotowali przyjaciele z ToMiTo, Książnicy Kopernikańskiej, Stowarzyszenia Absolwentów i z Chóru Lutnia, którego wprawdzie nie jest członkinią, ale systematycznie uczestniczy w jego koncertach. W trakcie uroczystości nie zabrakło specjalnie przygotowanego na tę okazję bukietu najpiękniejszych pieśni. O Jej życiu opowiedziały siostra Jubilatki Magdalena Lubieńska i Katarzyna Tomkowiak. 
Cecylia Maria z Łubieńskich Iwaniszewska - kobieta niezwykła i wielu talentów, Pierwsza Dama Toruńskiej Astronomii naszego Uniwersytetu Mikołaja Kopernika w Toruniu - w tym roku skończyła 90 lat. Trudno w to uwierzyć!

$\mathrm{Z}$ toruńską Alma Mater cztery pokolenia Jej rodziny związały także swą edukację, ukończyły toruńską uczelnię Jej mama Zofia ze Ślaskich Łubieńska (filologię angielską), siostra Maria Brykczyńska (filologię francuską), mąż Henryk i ona sama astronomię, Jej młodszy syn Jan fizykę, a wnuk Wojciech i jego żona Joanna - informatykę i matematykę.

$\mathrm{Na}$ Uniwersytecie Mikołaja Kopernika pracowała od 1947 do 1990 r. (będąc na emeryturze nadal prowadziła zajęcia dydaktyczne do 2007 r.). W trakcie Święta Uczelni w lutym 2010 r. została uhonorowana Medalem za Zasługi dla UMK, jak sama zaznaczyła, 20 lat po przejściu na emeryturę.

Urodziła się 24 listopada 1928 r. w Warszawie, w domu rodzinnym o tradycjach patriotycznych, zarówno ze strony rodziny Ślaskich z Trzebcza, jak i Łubieńskich. Cecylia urodziła się jako druga córka Zofii ze Ślaskich i Henryka Łubieńskich. Najstarsza była Maria, a najmłodsza Magdalena (która podobnie jak Cecylia związana jest z Toruniem). Do Torunia rodzina Cecylii dotarła dopiero w 1945 r. z Krakowa, przez Katowice, Inowrocław i Bydgoszcz. Jej mama, Zofia ze Ślaskich Łubieńska (siostra przedwojennego senatora Jana Ślaskiego), była autorką wierszyków, opowiadań i powieści dla dzieci, a po II wojnie światowej korespondentką „Ilustrowanego Kuriera Polskiego”, nauczycielką języków obcych w Liceum Ogrodniczym i Pedagogicznym w Toruniu. Ojciec, Henryk Łubieński, inżynier elektryk (urodzony w Jędrzejowie, a wykształcony w Petersburgu), po II wojnie światowej pracował na Górnym i Dolnym Śląsku. O polskość tego Śląska Zofia Ślaska zabiegala w czasie plebiscytu

Młoda Cecylia w trakcie wojny uczyła się częściowo w domu, a częściowo (przez 2,5 roku) w Szkole Ogrodniczej w Warszawie, gdzie uczęszczała razem ze starszą siostrą. Podczas nauki miała okazję zetknąć się z wysiedlonym z Torunia Antonim Ryniewiczem, przedwojennym kuratorem oświaty na Pomorzu, który wykładał tam literaturę pol- 
ską. Był on także ostatnim przedwojennym prezesem Towarzystwa Miłośników Torunia. Maturę zdała w Bydgoszczy 6 listopada 1945 r. (w II Liceum Ogólnokształcącym im. M. Kopernika) i w tym też miesiącu przybyła do Torunia, gdzie powstał uniwersytet. Zapisała się na matematykę, ale studiowała także astronomię. Ukończyła ją w 1950 r. jako pierwsza absolwentka tego kierunku w historii UMK. Początki astronomii toruńskiego uniwersytetu to czasy takich luminarzy polskiej nauki, jak profesorowie Władysław Dziewulski czy Wilhelmina Iwanowska. $\mathrm{Z}$ uczelnią dr Cecylia Iwaniszewska związała się także jako pracownik już w trakcie studiów, od 1 września 1947 r. pracowała jako zastępca młodszego asystenta przy Katedrze Astrofizyki u prof. Iwanowskiej. Później pracowała jako młodszy asystent tej Katedry, w 1959 r. po obronie doktoratu została adiunktem, a następnie starszym wykładowcą, aż do emerytury w 1989 r. W latach 1980-1984 pełniła funkcję zastępcy dyrektora Instytutu Astronomii UMK. Prowadziła wykłady i zajęcia dla studentów astronomii, fizyki, geografii oraz statystyki matematycznej dla geografów, biologów, fizyków i archeologów. „Na końcu mojej pracy uniwersyteckiej [w latach 90 . XX w.] poproszono mnie jeszcze o mały wykład statystyki dla kierunku fizyka medyczna".

Warto pamiętać, że początek Jej kariery zawodowej przypadał na czas represji stalinowskich, jak to sama wspomina: „w 1949 r. Ministerstwo Oświaty negatywnie załatwiło wnioski o zatrudnienie na UMK". Także Jej wniosek nie otrzymał akceptacji (tzn. nie wyrażono zgody na zatrudnienie w r. akad. 1949/1950, reskrypt MOś z 29 X 1949), ponieważ „POP PZPR na UMK usunęła 11 asystentów - wrogów obecnego ustroju, w ich miejsce wytypowano 26 ZMP-owców", tak odnotowano w sprawozdaniu tej organizacji z 22 listopada 1950. Taki los spotkał grupę wielu pracowników (Zofię Abramowiczównę, Leokadię Małunowiczównę, Zofię [Kalinę] Skłodowską-Antonowicz, Irenę Sławińską, Krystynę Swinarską, Kazimierza Ślaskiego, Waldemara Voisé, Aleksandrę Zajkowską, a od 31 marca 1949 r. Czesława Zgorzelskiego oraz od 1950 r. Andrzeja Tomczaka). Wówczas dorywczo wykonywała korekty tekstów naukowych, miała także stypendium im. prof. Juliusza Rudnickiego. A kiedy otrzymała pracę - etat na toruńskiej uczelni od września 1950 r. - oznaczało to dla jej siostry Marii, że ona etatu nie 
dostanie (pracowała wówczas w Bibliotece Uniwersyteckiej - zdała bardzo prestiżowy egzamin bibliotekarski na zasadach przedwojennych). Dwie Łubieńskie w jednej uczelni - to byłoby za wiele jak na tamte czasy. No i jeszcze jeden szczegół - Cecylia Iwaniszewska pochodzi z „tych” Łubieńskich, jej ojciec, Marian Henryk hrabia Łubieński i matka Zofia Ślaska wywodzili się z zasłużonych rodzin ziemiańskich - co wówczas było źle widziane.

Zawsze w szczególny sposób zajmowała się upowszechnianiem wiedzy o Mikołaju Koperniku i jego nauki. Bardzo zaangażowała się w obchody jubileuszowe Roku Kopernikańskiego - 1973. Nauczanie astronomii było i jest jej pasją. Przez dwie kadencje była przewodniczącą Komisji Nauczania Astronomii w Międzynarodowej Unii Astronomicznej. „Bardzo sobie ceniłam kontakty $\mathrm{z}$ astronomami zainteresowanymi nauczaniem. Mieliśmy [...] sekcję nauczania astronomii, w której pracowali ludzie $\mathrm{z}$ całego świata, przez jakiś czas byłam jej przewodniczącą. Tu powstały programy stypendialne, założenia letnich szkół, przy pomocy jednej z firm zakupiliśmy nieduży teleskop, który wędrował w różne miejsca w zależności od potrzeb".

Pani Profesor - tak do niej zwracają się całe pokolenia, Pani Dr Cecylia Iwaniszewska, Pani Cecylia, czy dla przyjaciół i bliskich Cesia - była i pozostaje bardzo skromną i pracowitą osobą. Jest członkinią i aktywnie pracuje w wielu towarzystwach naukowych i organizacjach społecznych, m.in. w Polskim Towarzystwie Astronomicznym (od 1950 r., pracowała w zespole do spraw nauczania i programów szkolnych), także Międzynarodowej Unii Astronomicznej (od 1958) oraz Europejskim Towarzystwie Astronomicznym (od 1992); Towarzystwie Naukowym w Toruniu (od 1961, od 1970 w Wydziale III, m.in. była redaktorem serii wydawnictw astronomicznych oraz przez 17 lat przewodniczyła Komitetowi Redakcyjnemu Wydawnictw Popularnonaukowych); Towarzystwie Miłośników Torunia (od 1 września 1965 r. w ToMiTo, od 1967 pełni funkcje w Zarządzie, jako sekretarz od listopada 1979 do 1987, ponownie sekretarz od 1996 do 2017, aktualnie pozostaje członkiem Zarządu). Bierze aktywny udział w corocznej kweście na cmentarzu św. Jerzego w Toruniu, a dzięki tej akcji udało się do tej pory odnowić wiele nagrobków znakomitych torunian. Działa także 
w Klubie Inteligencji Katolickiej w Toruniu (jego członkinią jest od 1983, funkcję prezesa KIK-u pełniła od 16 kwietnia 1994 do 24 kwietnia 2017 r., obecnie jest wiceprezesem). Nasza Cecylia chętnie opowiada o początkach duszpasterstwa akademickiego w Toruniu, gdyż sama je współtworzyła, ale także w końcu lat 40. działała w Sodalicji Mariańskiej Akademiczek. Została uhonorowana medalem Marszałka Województwa Kujawsko-Pomorskiego „Unitas Durat Palatinatus CuiavianoPomeraniensis" (wyróżnienie zostało przyznane z okazji 60-lecia istnienia KiK-u w mieście w 2017 r.). Jest także członkiem władz Stowarzyszenia Absolwentów UMK w Toruniu, Zarządu i Rady. Pomaga społecznie w pracach Biura Stowarzyszenia. Z powodzeniem realizuje misję popularyzacji astronomii, a to dzięki działalności w Toruńskim Oddziale Towarzystwa Miłośników Astronomii (do PTMA wstąpiła w pierwszej połowie lat siedemdziesiątych $\mathrm{i}$ jest jednym $\mathrm{z}$ dwóch najstarszych stażem członków Towarzystwa, drugim jest prof. Jan Hanasz), pełniła różne funkcje w Zarządzie Toruńskiego Oddziału PTMA. Zaangażowała się jako juror od początku istnienia Wojewódzkiego Konkursu z Fizyki i Astronomii organizowanego od 1990 r. przez PTMA dla uczniów szkół podstawowych, a następnie gimnazjalnych. Walny Zjazd Delegatów PTMA uhonorował ją złotą odznaką PTMA, a za działalność w PTMA i za popularyzację astronomii otrzymała Medal Komisji Edukacji Narodowej. Była także członkiem Głównego Komitetu Ogólnopolskiej Olimpiady Astronomicznej. To z jej inspiracji Toruński Oddział PTMA w 2017 r. podpisał umowę z Książnicą Kopernikańską w Toruniu, co spowodowało wznowienie w bibliotece tradycyjnych otwartych wykładów dla wszystkich miłośników astronomii. Zatem nasza Cesia często uczestniczy w uroczystościach, jakie odbywają się w tej najstarszej książnicy w Toruniu, gości zarówno na imprezach ToMiTo, jak i tych organizowanych przez miłośników astronomii. Jest członkinią Oddziału Uniwersyteckiego Polskiego Towarzystwa Turystyczno-Krajoznawczego oraz współzałożycielką Klubu Turystyki Górskiej „Karpaty” w Toruniu. Kiedyś razem z mężem chętnie uczestniczyła w pieszych wędrówkach górskich.

Żona astronoma Henryka Iwaniszewskiego (1922-1981), ma dwóch synów (archeologa Stanisława i fizyka Jana) i czwórkę wnuków, naj- 
starszy, Maciek, przygotował do druku Jej wspomnienia i zaprojektował okładkę książki - wydawnictwa Towarzystwa Miłośników Torunia Wspomnienia o moim uniwersytecie (Toruń 2014). Na okładce trafnie zamieścił witraż nad wejściem do budynku Obserwatorium Astronomicznego w Piwnicach - bo astronomia zdominowała życie babci od studiów, aż do tej chwili. Mimo swych 90 lat w styczniu tego roku na promocji wydawnictw ToMiTo prezentowała kolejny raz swe wspomnienia czy na zebraniu PTMA pilnowała terminowej wpłaty składek. Jej energia do działania jest nie z tego świata. A przecież zanim powstały wspomnienia, była popularna książeczka o Obserwatorium Astronomicznym w podtoruńskich Piwnicach. Warto przypomnieć, że do tego przybytku nauki, faktycznie majątku uniwersyteckiego, dojazd u jego zarania był trudny. Od ciężarówki Pana Lewandowskiego, po regularne połączenie kolejowe czy autobusowe. Od zabudowań dworskich i folwarcznych, gdzie były warzywnik, sad i las (bliskość rezerwatu dębów), przejście przez kładkę nad strumykiem zwanym Rzeką Eridanus (od gwiazdozbioru na niebie południowym), przez polanę zwaną Mare Serenitatis (od księżycowego Morza Spokoju), po polną drogę... do budynków współczesnych - taki spacerek przez lata całe.

Niektóre z Jej wielu prac dotyczą dydaktyki. „Starałam się uczyć. Przez moje ręce przeszło blisko dziewięć tysięcy studentów, prawie nie ma w Toruniu większego grona, w którym ktoś z moich byłych studentów by się nie znalazł". Nadal swą wartość poznawczą zachowuje monografia Jej autorstwa Astronomia Mikołaja Kopernika. Jest również redaktorem i współautorem dwóch prac zbiorowych poświęconych historii astronomii: Astronomia w Toruniu mieście Mikotaja Kopernika (wersja angielska Astronomy in Toruń Nicholas Copernicus' native town) oraz Władysław Dziewulski (1878-1962). Napisała także cieszący się uznaniem skrypt, obejmujący zakres wykładów z matematyki, które prowadziła dla studentów biologii.

Dr Cecylia Iwaniszewska przez wiele lat swojej pracy naukowej i dydaktycznej na naszej uczelni, ale i w Towarzystwie Miłośników Torunia oraz $\mathrm{w}$ wielu stowarzyszeniach, zasłużyła się miastu i nauce, w szczególności toruńskiej astronomii i popularyzacji nauki Mikołaja 
Kopernika, który stał się wizytówką całego regionu. Przez długie lata, na dobre i na złe, była z nami, za co Jej wszyscy serdecznie dziękujemy.

A z okazji dziewięćdziesiątych urodzin życzymy, by nie zabrakło Jej zdrowia i energii do dalszych działań.

Przyjaciele z Towarzystwa Miłośników Torunia (tekst przygotowała Katarzyna Tomkowiak)

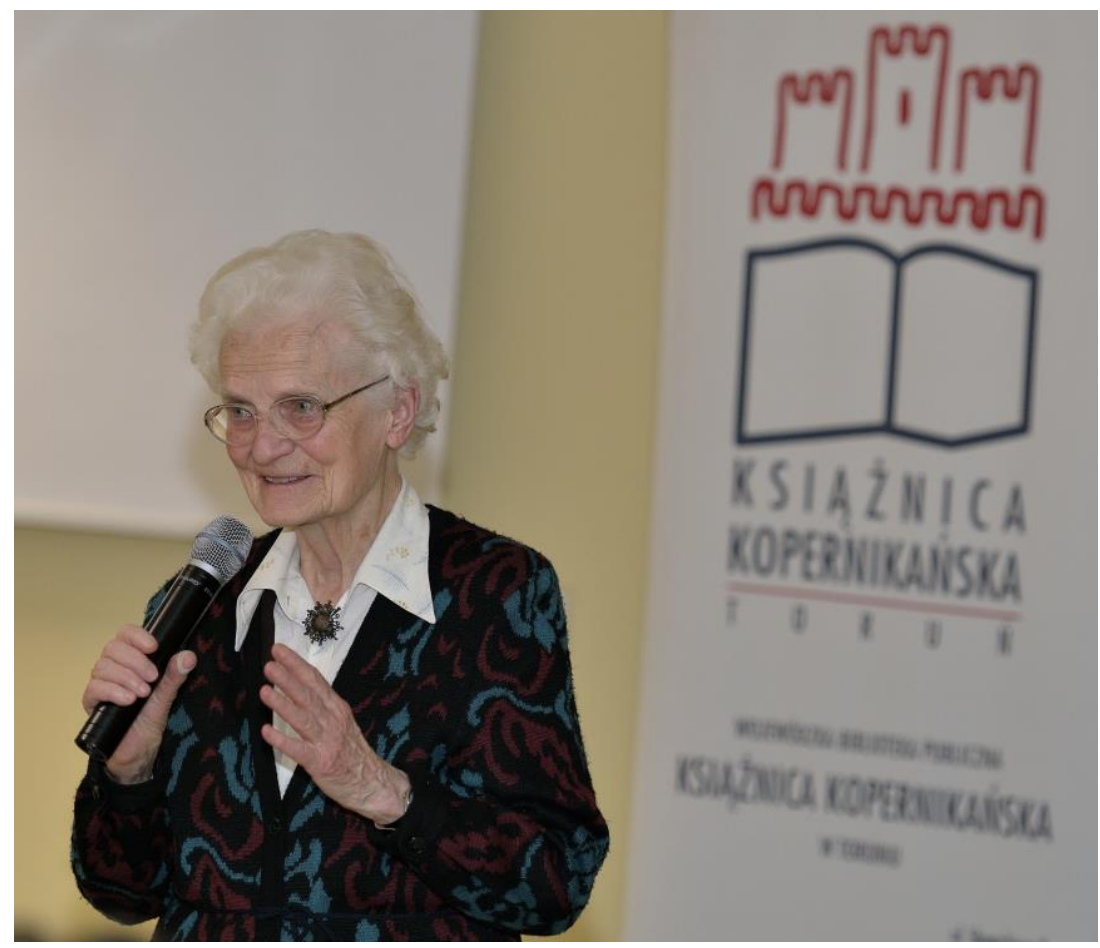

Cecylia Iwaniszewska w trakcie promocji wydawnictw ToMiTo, Książnica Kopernikańska, 2018, fot. T. Dorawa 

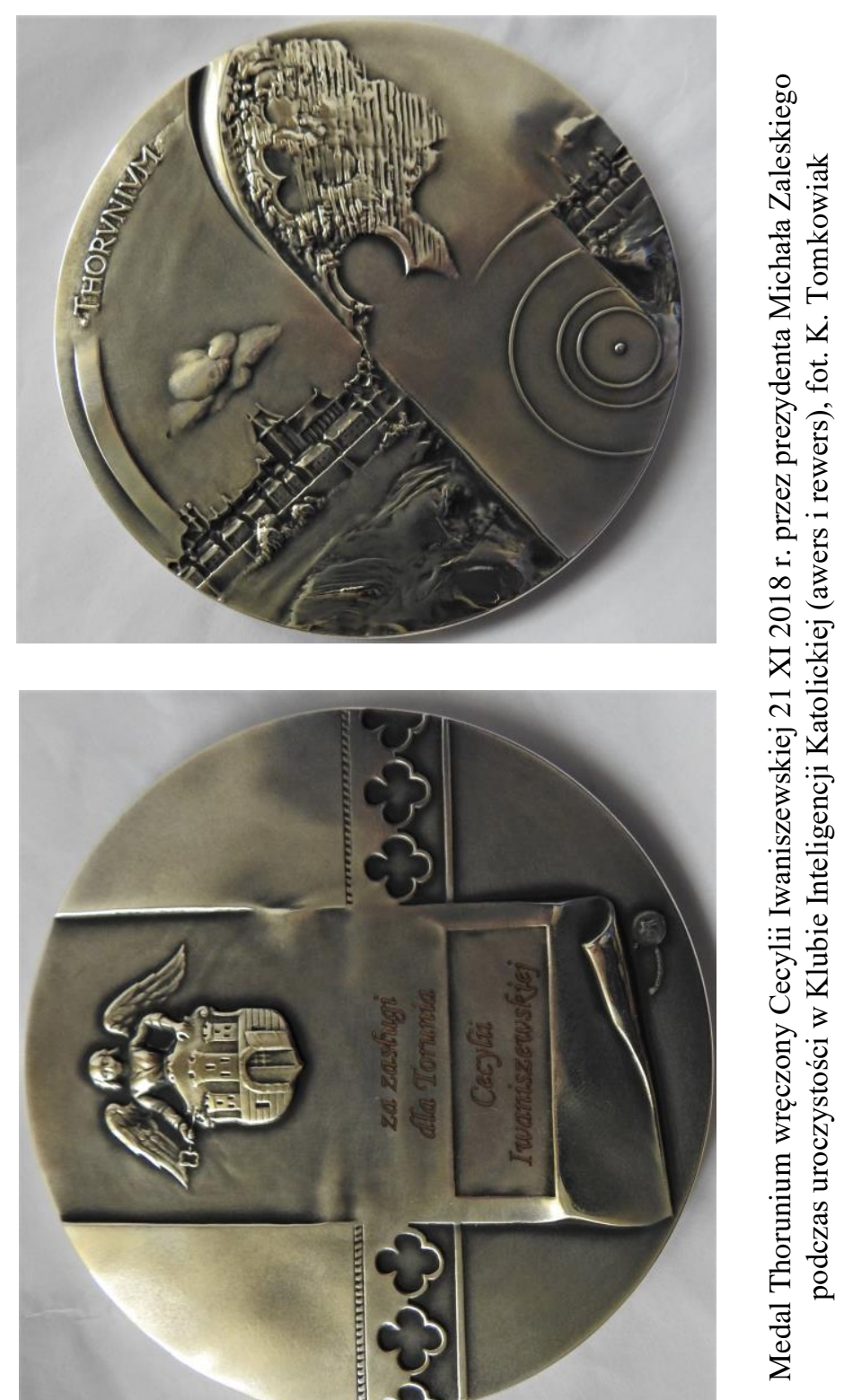


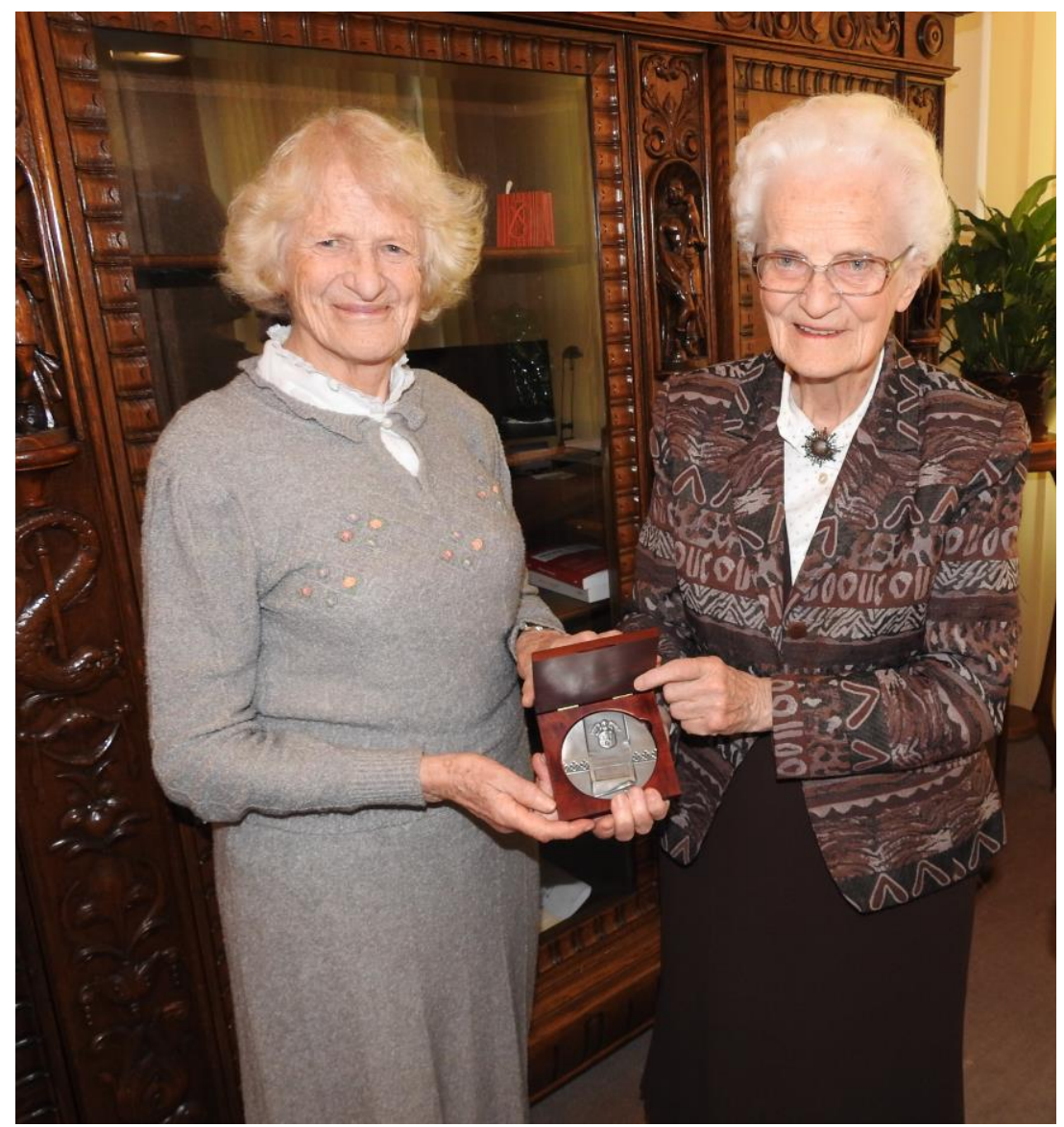

Cecylia Iwaniszewska z siostrą Magdaleną prezentują Medal Thorunium, Książnica Kopernikańska 28 XI 2018 r., fot. K. Tomkowiak 


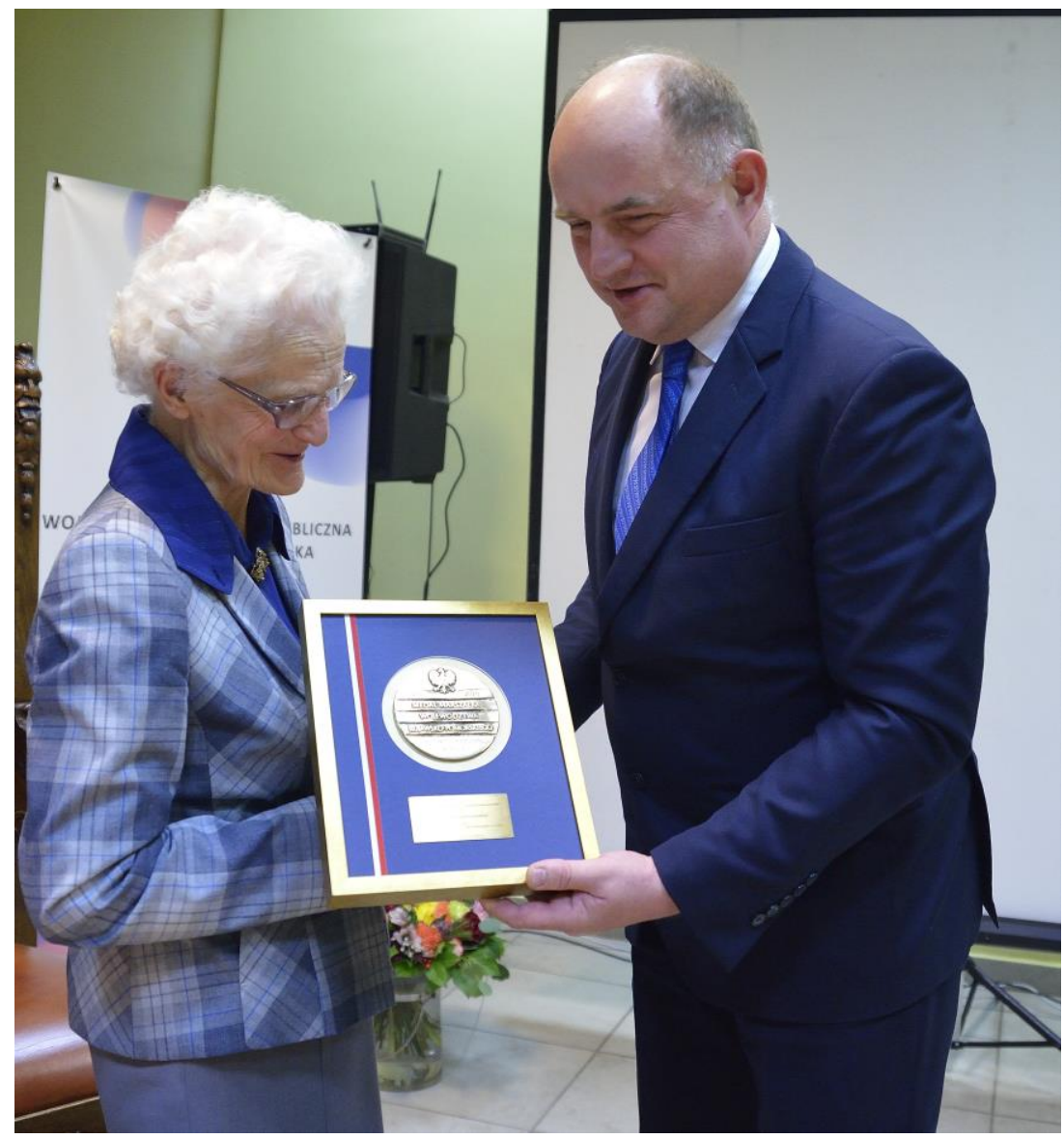

Piotr Całbecki wręcza Cecylii Iwaniszewskiej Medal Marszałka Województwa Kujawsko-Pomorskiego z okazji 100 lat Niepodległości, Książnica Kopernikańska, 29 XI 2018 r., fot. T. Dorawa 


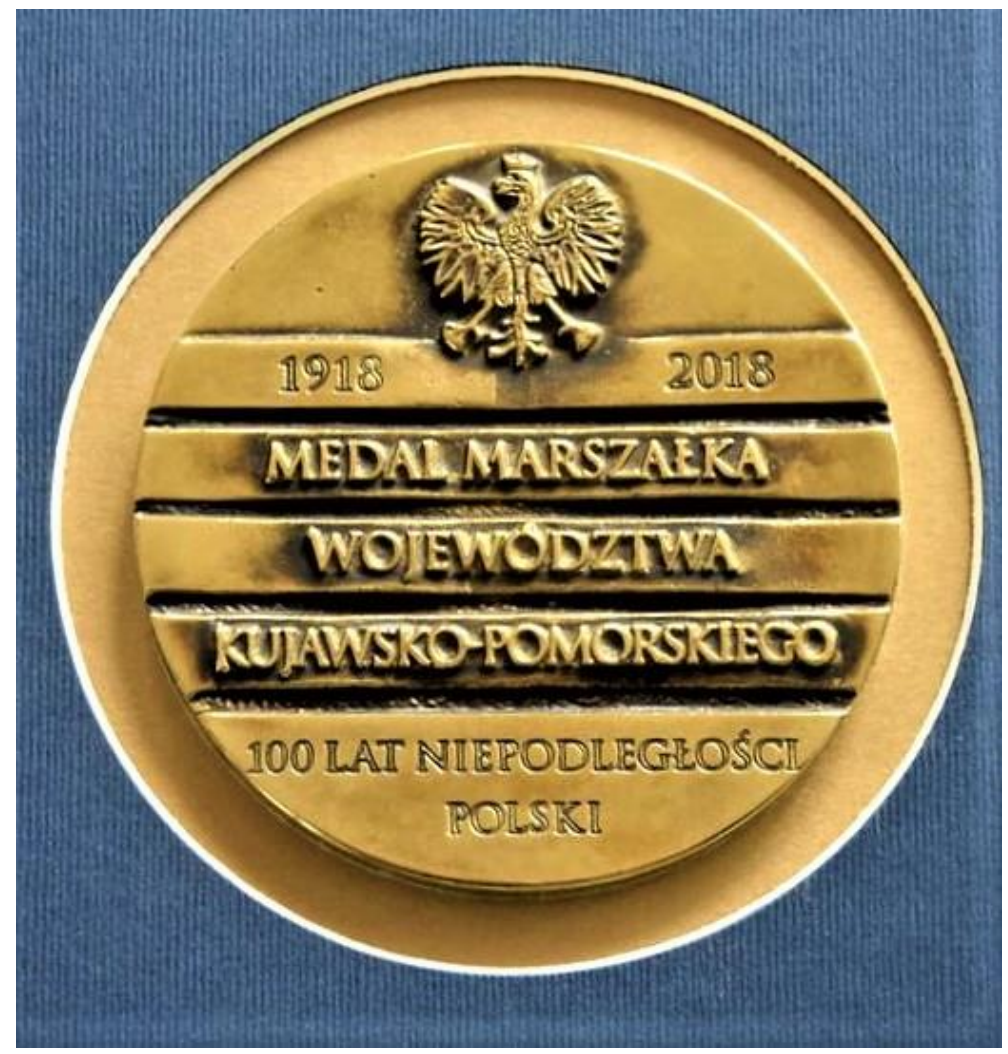

Medal Marszałka Województwa Kujawsko-Pomorskiego z okazji 100 lat Niepodległości, fot. K. Tomkowiak 